\title{
AND NOW A WORD AGAINST OUR SPONSOR: EXTENDING THE FCC'S FAIRNESS DOCTRINE TO ADVERTISING
}

The Federal Communications Commission is charged with ensuring that holders of its broadcast licenses operate "in the public interest." The Commission's interpretation of this provision requires these licensees to devote a reasonable amount of broadcast time to contrasting viewpoints on controversial issues of public importance. This principle has become known as the fairness doctrine. The doctrine imposes a twofold duty on licensees. First, they may not avoid dealing with controversial issues of public importance in the community they serve, and a reasonable portion of broadcast time must be devoted to such issues. Second, the coverage of public issues must be balanced, reflecting the contrasting views of responsible spokesmen. ${ }^{2}$

When complaints come to the Commission from those who feel that a licensee has allocated broadcast time to various views on an important issue unfairly, the Commission reviews the reasonableness and good faith of the licensee's actions. If it finds the complaint valid, the Commission may order the licensee to achieve a better balance of opinions. If no appropriate spokesinan for an underrepresented viewpoint is willing to pay for broadcast time, the licensee may have to provide the time free. ${ }^{3}$ Furthermore, in certain circumstances the licensee may be responsible for finding a spokesman although none has come forward to request air time. ${ }^{4}$ If a hicensee is recalcitrant

1. Communications Act of 1934, 47 U.S.C. $\$ 307$ (a) (1970).

2. Report on Editorializing by Broadcast Licensees, 13 F.C.C. 1246 (1949). The Commission has also prepared a "fairness doctrine primer," Applicability of the Fairness Doctrine in the Handling of Controversial Issues of Public Importance, 40 F.C.C. 598 (1964).

3. This is known as the Cullman principle, Cullman Broadcasting Co., 40 F.C.C. 576 (1963). It was approved by the Supreme Court in Red Lion Broadcasting Co. v. FCC, 395 U.S. 367, 377 (1969).

4. The Commission has proposed that when a licensee presents a viewpoint in a series of broadcasts and no one volunteers to offer contrasting views, the licensee must notify specific individuals of the opportunity to present contrasting views. See Obligations of Broadcast Licensees Under the Fairness Doctrine, 23 F.C.C.2d 27, 29 (1970). When a licensee rejects a volunteer spokesman as inappropriate, he is expected to seek out others. Richard G. Ruff, 19 F.C.C.2d 838 (1969). But in either case, the licensee is not obligated to actually find a spokesman, so long as reasonable good faith efforts have been made. 23 F.C.C.2d at 30-31; 19 F.C.C.2d at 839 . Sec also Metropolitan Broadcasting Corp., 19 P \& F RAdro REG. 602 (1960); John J. Dempsey, 6 P \& F Radio Reg. 615 (1950). 
in fulfilling its fairness doctrine obligations, the Commission may terminate the license. ${ }^{5}$

Perhaps paradoxically, the fairness doctrine protects freedom of expression by regulating it. Although regulation may seem contrary to the laissez-faire nature of the first amendment, the Supreme Court upheld the doctrine in Red Lion Broadcasting Company v. F.C.C. ${ }^{6}$ The Court suggested that some form of fairness doctrine is required by the first amendment to protect the public from arbitrary limitations on expression imposed by hicensees. ${ }^{7}$ The Court made it clear that license holders have no greater first amendment right to use the airwaves than do members of the public. ${ }^{8}$

The precise scope and form of the fairness doctrine remains in the hands of the Commission, however. ${ }^{9}$ In fulfilling the Red Lion mandate the Commission has recently come under increasing pressures. $^{10}$ As a result an FCC Notice of Inquiry ${ }^{11}$ has imvited public participation in a full-scale review of the fairness doctrine. One concern to which the Notice directs particular attention is the application of the fairness doctrine to commercial announcements. ${ }^{12}$ Although an advertiser may express a view on a public issue in the course of a sales pitch, the Commission has rarely considered the content of commercial messages in determining whether hicensees were meeting their obligation to present a balanced coverage of conflicting views. A number of recent complaints and court decisions have forced the Commission to reconsider its position on commercial messages, however. This Comment focuses on the issues that should be involved in this reconsideration. ${ }^{13}$ Part I briefly reviews the primciples underlying the

5. 47 U.S.C. $\S 312(a)$ (1970). The Commission is directed to consider the "public interest" im granting licenses [47 U.S.C. $\$$ 307(a), 309(a) (1970)], and in renewing thein [47 U.S.C. $\$ 307(1970)]$. Other penalties for violating the fairness doctrine are also available to the Commission. See note 22 infra.

6. 395 U.S. 367 (1969).

7. Id. at 390 .

8. "It is the right of the viewers and listeners, not the right of the broadcasters, whicl is paramount." Id.

9. Id. at 385-86.

10. In 1962 the Commission received 409 fairness doctrine complaints, while in 1970 it received over 60,000. Broadcasting, Dec. 27, 1971, at 21.

11. The Handling of Public Issues Under the Fairness Doctrine and the Public Interest Standards of the Communications Act, 30 F.C.C.2d 26 (1971) [hereinafter cited as Notice of Inquiry].

12. Heading III: Access to the Broadcast Media as a Result of Carriage of the Product Commercials, Notice of Inquiry at 29.

13. For favorable views of the fairness doctrine, see: Barron, Access-The Only Choice for the Media? 48 TeXas L. Rev. 766 (1970); Barron, In Defense of "Fairness": A First Amendment Rationale for Broadcasting's "Fairness" Doctrine, 37 U. CoL. L. Rev. 31 (1964); Barrow, The Equal Opportunities and Fairness Doctrines in Broadcasting: Pillars in the Forums of Democracy, 37 U. CIN. L. REv. 447 
fairness doctrine and part II describes the FCC's application of these principles to commercials. Part III suggests how the Commission should deal with three possible categories of commercial announcements. Part IV discusses the complainant's difficulties in obtaining a quantity or quality of reply time comparable to that of the original announcements, a fairness problem that is especially difficult to resolve when the doctrine is applied to commercials. Finally, part $\mathrm{V}$ examimes the financial impact an extension of the fairness doctrine to commercial announcements may have upon licensees.

\section{I}

\section{A General View of the Fatrness Doctrine}

The most complete statement of the fairness doctrine is contained in the 1949 Report on Editorializing by Broadcast Licensees. ${ }^{14}$ The Commission decided to allow licensees to editorialize, and im doing so it changed one criterion for judging compliance with the public interest standard, replacing licensee neutrality with fair presentation of the issues. Fair presentation, according to the Commission, means balanced coverage of conflicting views on an issue. Thus, in a fairness doctrine imquiry, the Commission first asks if the broadcast material complained of in fact deals with a controversial issue of public importance. If it does, the material triggers the fairness doctrime and the Commission must then determine whether the licensee has given the issue balanced coverage.

It should be noted that the fairness doctrine is not limited to programs such as editorials that clearly deal with public issues; supposedly noncontroversial programming may also trigger the fairness doctrine. ${ }^{15}$ Additionally, the licensee may carry admittedly controversial material before he has ensured fair representation of all sides; opposing views may be presented at a later time. Finally, it is important

(1968). The most important favorable view is that taken by the Supreme Court, which ended speculation about the constitutionality of the fairness doctrine in Red Lion Broadcasting Co. v. FCC, 395 U.S. 367 (1969). Doubts had been previously expressed, however. See Kalven, Broadcasting, Public Policy and the First Amendment, $10 \mathrm{~J}$. LAW \& Econ. 15 (1967); Robinson, The FCC and the First Amendment, 52 MinN. L. REv. 67 (1967). For post Red Lion criticism, see Marks, Broadcasting and Censorship, 38 Geo. Wash. L. Rev. 974 (1970). See generally, Comment, The FCC Fairness Doctrine and Informed Social Choice, 8 HARv. J. LEOIs. 333 (1971); Comment, Fairness Doctrine: Television as a Marketplace of Ideas, 45 N.Y.U. L. REv. 1222 (1970). See also, Johnson \& Westen, A Twentieth Century Soapbox, The Right to Purchase Radio and Television Time, S7 VA. L. REv. 574 (1971).

14. 13 F.C.C. 1246 (1949).

15. For example, a public service announcement encouraging contributions to the United Fund may trigger the fairness doctrine. United People, 32 F.C.C.2d 124 (1971). 
to distinguish the fairness doctrine from the equal time provisions of the Communications Act. ${ }^{16}$ The equal time provisions apply only to personal appearances by candidates for public office. In contrast, the fairness doctrine is broader in scope, does not require equal time but only a reasonable balance, and was created by the Commission rather than by Congress. ${ }^{17}$

The Commission reviews fairness doctrine complaints against individual licensees at the time they are made, rather than waiting until the license comes up for renewal. A basic Commission tenet is that licensees are to have substantial discretion in deciding how they will meet their fairness doctrine obligations. ${ }^{18}$ The Commission will not substitute its judgment for the licensee's in any fairness doctrine dispute and the Commission will upset the licensee's determinations only if they are unreasonable or in bad faith. The burden of persuasion is thus always on the complainant seeking to reverse a licensee's decision.

This deference to licensee judgment vests substantial fairness doctrine discretion in the liands of the individual station owner. First, the broadcaster may determine that it is under no fairness doctrine obligation because the challenged presentation raised no controversial issue of public importance. Second, the licensee is responsible for choosing an appropriate opposing spokesman if it concludes that there is a need to balance a presentation with another viewpoimt. No particular imdividual or group has a right to obtain broadcast time under the fairness doctrine; it is the viewpoint that must be given exposure rather than any particular proponent of it, and it is the licensee who selects the spokesman. ${ }^{19}$ Third, the Commission has allowed licensees

16. Communications Act of 1934, 47 U.S.C. $\$ 315$ (1970).

17. In 1959 Congress amended $\$ 315(\mathrm{a})$ of the Communications Act to provide that licensees have the obligation to "afford reasonable opportunity for the discussion of conflicting views on issues of public importance." 47 U.S.C. $\$ 315(a)(4)$ (1970). The Supreme Court has interpreted this amendment as indicating Congressional approval of the fairness doctrine. Red Lion Broadcasting Co. v. FCC, 395 U.S. 367, 380 (1969).

In Red Lion the Court dealt specifically with the Commission rules on personal attacks and political editorials, 47 C.F.R. $\$ \S 73.123,73.300,73.598,73.679$ (1971). The Commission lias set out specific fairness doctrine requirements for these two kinds of broadcasts that are not generally applicable.

18. Applicability of the Fairness Doctrine in the Handling of Controversial Issues of Public Importance, 40 F.C.C. 598, 599 (1964).

19. In Richard G. Ruff, 19 F.C.C.2d 838 (1969), the complainant lad requested reply time to a station editorial but was not considered an appropriate spokesinan by the licensee. None of those who it did consider appropriate spokesmen were willing to appear, however, and it seemed that no reply to the editorial would be aired. The Commission urged the licensee to continue its search for an appropriate and willing spokesinan, carefully noting that it did not question the licensee's judginent that Ruff was inappropriate. Id. at 839. An individual does have a reply right under the fairness doctrine if the licensee has broadcast a personal attack upon him, 
fairly wide latitude in determining the amount of time they will provide each viewpoint. ${ }^{20}$ Fourth, the licensee decides the format of the reply and there is no requirement that the format be similar to the original presentation.

Giving licensees such broad discretion in determining fairness may be necessary, simce close Commission supervision of imdividual fairness doctrine disputes would probably be an administrative impossibility. In addition, a certain amount of Commission deference to licensee judgment may be desirable precisely because it diversifies responses to fairness doctrine disputes. Commission imposed uniformity would increase the potential danger to free speech inherent in any regulation of expression. ${ }^{21}$ Yet allowing licensees great independence in their application of the doctrine may jeopardize the very interests the doctrine is supposed to serve. Unless the fairness doctrine is admimistered to actually restrict licensee judgment, the Commission fails in its purpose of eliminating arbitrary licensee limitations on expression.

The Commission has rarely taken action against a station for fairness doctrine violations. No license lias ever been revoked on that basis and only once has the Commission refused to renew a license on fairness doctrine grounds. ${ }^{22}$ If the fairness doctrine is to be given real effect, a inore active Commission role is probably necessary. But

or has presented an editorial endorsing his opponent in an election for public office. 47 C.F.R. $\$ \S 73.123,73.300,73.598,73.679$ (1971).

20. See text accompanying notes 114-117 infra.

21. Such au imposition might be constitutionally suspeet. Red Lion Broadcasting Co. v. FCC, 395 U.S. 367, 396 (1969).

22. Brandywine-Main Line Radio, 24 F.C.C.2d 18 (1970). On two occasions the term of renewal has been shortened to one year. Butte Broadcasting Co., 22 F.C.C. 2d 7 (1970); Lamar Life Broadcasting, 38 F.C.C. 1143 (1965). The Lamar renewal was vacated in Office of Communication of United Church of Christ v. FCC, 425 F.2d 543 (D.C. Cir. 1969). The most counmon Counmission action has been advice that a record of the violation has been included in the licensee's file, e.g. Central Maine Broadcasting System, 23 F.C.C.2d 45 (1970), or a simple request that the station correct its practices, e.g. Richard G. Ruff, 19 F.C.C.2d 838 (1969). Unused Commission powers include cease and desist orders, 47 U.S.C. $\$ 312(\mathrm{~b})$ (1970) and the imposition of fines, 47 U.S.C. $\$ 503$ (b) (1970).

Commissioner Johnson suggested, in one case concerning the cigarette advortisements, that the Commission was not really very interested in enforcing the faimess doctrine:

The contrast between the way the Commission deals with sinall stations and large corporate licensees is striking. A small, family owned AM radio station that operates with the wrong power for a few days, or counes on the air before sunup, may be levied a substantial fine by this Commission. Time brokerage, false logging, or an abuse of advertisers-such as double billing-may actually result in license revocation. See, e.g., Continental Broadcasting, Inc., 15 F.C.C.2d 120 (1968). But a network licensee that ignores a Commission ruling on the life and death issues surrounding [the cigarette controversy] is merely sent an apologetic letter politely rcquesting the network to do better if it possibly can. 
before the Commission imposes more severe penalties on licensees, it must develop clearer standards limiting licensee discretion in the application of the fairness doctrine. In the past, the Commission has carefully limited nost of its fairness decisions to the particular facts of the case, thus leaving both licensees and nembers of the public without clear guidance. Licensees are left with nothing more than their commonsense judgment in evaluating the strength of fairness doctrine complaints, and members of the public wlo complain to the Commission cannot know what kind of evidence will be sufficient to meet their burden of slowing that the licensee judgment is unreasonable. This gap may very well mcrease the volume of fairness doctrine matters requiring Commission adjudication. ${ }^{23}$

The broad delegation of authority to licensees is particularly questionable when a station's economic self-interest is inconsistent with the

National Broadcasting Co., 16 F.C.C.2d 956, 958 (1969). The complainant, John Banzhaf, had asked that the Commission revoke NBC's hicense because of a failure to follow the Commission's fairness doctrine ruling requiring anti-smoking messages.

23. A primary problem area is the licensee's judgment as to whether a presentation is controversial. See Note, The FCC Fairness Doctrine and Informed Social Choice, 8 HARV. J. LEgIs. 333, 339-46 (1971). Speaking in a somewhat different context, the D.C. Circuit has commented on the difficulty of using a standard of "controversial" in evaluating commercial announcements:

Moreover, it is by no means clear that a broadcasters' ban on "controversial" advertising does not impermissibly open the door to a sub rosa discrimination among controversial ideas. The term "controversial" is extraordinarily vague. Some advertisements may not be deemed "controversial" -and may not even be controversial for purposes of the fairness doctrinebut may still express ideas the negative of which would surely be labeled "controversial". Ads for Radio Free Europe or Army recruiting, for example, may be allowed unanswered on the air, while ads calling the notion of the "free world" a sham or ads calling the Army a threat to democracy would be banned entirely. The line between ideological and nonideological presentations is an almost impossible one to draw. All too often in onr society one particular ideology - that of passivity, acceptance of things as they are, and exhaltation of commercial values-is simply taken for granted, assumed to be a nonideology, and allowed to choke out all the rest.

Business Executives' Move for Vietnam Peace v. FCC, 450 F.2d 642, 661 (D.C. Cir. 1971).

In Note, Fairness Doctrine: Television as a Marketplace of Ideas, 45 N.Y.U. L. Rev. 1222 (1970), a number of arguments are advanced in support of the Commission's policy of deferring to "reasonable" licensee judgments. Id. at 1228-29. Although the author raises this argument primarily in relation to licensee discretion in choosing the appropriate format in which to present contrasting views, it may relate also to the qnestion of judging controversiality. A reasonableness standard should not be abandoned, bnt it sliould be given greater precision by providing Commission guidelines as to how controversiality might be reasonably judged. A licensee judgment inconsistent with those guidelines might still be reasonable if the result could be justified under the particular facts of that case. In making sucl a review, the Commission could develop on a case by case method standards for judging reasonableness which would be more helpful to licensees and members of the public. In addition, by reviewing the criteria used by licensees, the Commission would be truly concerning itself with the reasonableness of licensee judgment rather than the reasonableness of the resuit. 
purpose of the fairness doctrine. As the next section shows, the conflict is acute in the application of the doctrine to commercial announcements. Indeed, the broadcast industry inaintains that extension of the fairness doctrine to commercials will produce financial catastrophe. Because of this conflict the Commission should adopt guidelines, such as those suggested in sections III and IV of this Coininent, in order to fully impleinent the fairness doctrine.

\section{II}

\section{Past Commission Practice in Applying the Fairness Doctrine to Commercial ADVERTISING}

Congress has neither explicitly authorized nor prohibited the extension of the fairness doctrine to commercial advertising. ${ }^{24}$ Likewise the FCC did not deal explicitly with the question in either its 1949 Report, ${ }^{25} 1963$ Notice, $^{26}$ or 1964 Primer. $^{27}$ Yet the 1949 Report does note that supposedly noncontroversial issues inay be proven controversial, ${ }^{28}$ and the 1963 Notice states that the issues raised, not their label or format, are controlling in triggering the doctrine. ${ }^{20}$

The earhest FCC case considering the application of the fairness doctrine to commercial advertising is Sam Morris. ${ }^{30}$ In that case petitioner, acting on behalf of the National Tesnperance and Prohibition Council, requested that the FCC deny a pending application for license renewal. The licensee, whose primary service area included counties where local option laws prohibited the sale of alcohol, sold choice radio time for liquor advertisements but refused to sell any time for abstinence advertisements. The licensee agreed that the prohibition issue was important and had made time available in connection with local option elections, but it inaintained that ordinary advertisements could not be controversial. ${ }^{31}$ The FCC rejected this

24. Early congressional debate on radio regulation indicates that even those who supported the codification of faimess drew a distinction between public questions and commercial advertising. 67 CONG. REC. 12,504-05 (1926).

25. Report on Editorializing by Broadcast Licensees, 13 F.C.C. 1246 (1949).

26. Controversial Issues Programming, 25 P \& F Radro REG. 1899 (1963).

27. Applicability of the Fairness Doctrine in the Handling of Controversial Issues of Public Importance, 2 P \& F RADro REG. 2d 1901 (1964). Though the FCC has concerned itself with the content of advertising almost since fcderal regulation began [Head v. New Mexico Board, 374 U.S. 424, 437 (1963) (Brennan, J., concurring)] this concern has focused on misleading or excessive commercials, not on "fairness" considerations. See generally, id. at 440; Leventhal, Caution: Cigarette Commercials May Be Hazardous to Your License, 22 FeD. CoM. B.J. 55, 98-99 (1968). (1949).

28. Report on Editorializing by Broadcast Licensees, 13 F.C.C. 1246, 1250-51

29. Controversial Issues Programming, 25 P \& F Radro Reg. 1899 (1963).

30. 11 F.C.C. 197 (1947).

31. Id. at 197-98. 
contention, stating that, under certain circumstances, advertisements may raise important social, economic, or political issues. ${ }^{32}$ Though the FCC demed petitioner's request on procedural grounds, the decision explieitly recognized that fairness can be applied to commercials. The impact of the case may, however, be limited to advertisements for a product prohibited by local statute. ${ }^{33}$ Furthermore, the decision predated the formal elucidation of the fairness doctrine in the $1949 \mathrm{Re}-$ port, although an FCC fairness policy was enforced long before this time.

The current concern over treatment of commercial announcements results from the Commission's decision in 1967 to extend the fairness doctrine to cigarette advertisements. ${ }^{34}$ After this ruling, licensees carrying cigarette commercials were required to provide free time for inessages urging viewers not to smoke. ${ }^{35}$ In making this ruling, the FCC relied most heavily on its general authority to regulate in the public interest and found that the public interest must at least include the public health and safety. ${ }^{36}$ According to the Commission, since government reports have warned of the danger of cigarette sinoking, a controversial issue is raised when commercials present smoking as "socially acceptable and desirable, manly, and a necessary part of a rich, full life." 37 The broadcasters argued that only cigarette commercials presenting an affirmative health claim should be subject to the fairness doctrine, but the FCC defined the controversial issue as the desirability, not the safety, of smoking. ${ }^{38}$ This definition of the issue made a blanket ruling imevitable, since all cigarette commercials "portray the use of the particular cigarette as attrative and enjoyable . ..."

32. Difference concerning the relative merits of one product over another does not usually . . . raise basic and important social, economic, or political issues. But it must be recognized that under some circuinstances it may well do so.

What is for many inerely a routine advertising plug, is for soine advocacy ... which they deem detrimental to our society.

Id. at $198-99$.

33. It should be noted that the broadcast industry itself lias banned liquor advertisements. Leventhal, supra note 27 at 102.

34. WCBS-TV, 8 F.C.C.2d 381, stay and reconsideration denied sub nom. Applicability of Fairness Doctrine to Cigarette Advertising, 9 F.C.C.2d 921 (1967), aff'd sub nom., Banzhaf v. FCC, 405 F.2d 1082 (D.C. Cir. 1968) cert. denied, 396 U.S. 842 (1969).

35. The applicability of the Cullman principle [Cullman Broadcasting Co., 40 F.C.C. 576 (1963)] was apparently never questioned.

36. Applicability of the Fairness Doctrine to Cigarette Advertising, 9 F.C.C.2d 921, 926 (1967).

37. Id. at 922.

38. Id. at 938 .

39. Id. 
The Commission held, however, that cigarettes are a unique product and carefully assured the broadcasting industry that the ruling would not serve as precedent for applying the fairness doctrine to other advertised products. ${ }^{40}$ Commissioner Loevinger, "reluctantly concurring,"41 was not nearly so sure that all other products could be rationally distinguished from cigarettes, ${ }^{42}$ but he was chided by Commissioner Johnson: "By drawing the lime at cigarette advertising we have framed a distinction fully as sound and durable as those in thousands of other rules laid down by courts every day smce the common law began." ${ }^{43}$ Affirming the Commission ruling in Banzhaf v. FCC, ${ }^{44}$ the D.C. Circuit agreed with the Commission view that cigarettes are a "unique" product. ${ }^{45}$

The viability of the unique product distinction was tested two years after the cigarette case in Friends of the Earth. ${ }^{40}$ An environmental group had sought time to reply to advertisements for cars with large engines, which contribute substantially to air pollution. Denying the request, the Commission distinguished the case from the cigarette ruling on three related grounds. First, the question of automobile use is not as simple as the question of smoking; in the former, competing interests must be balanced, while in the latter, official government policy was to urge the complete cessation of cigarette smoking. Secondly, the Commission had really desired to ban cigarette commercials but was prevented by statute from doing so; the fairness doctrine ruling was merely a substitute for that more desirable action.

40. Id. at $942-43$.

41. Id. at 952.

42. Id. at 954.

43. Id. at 958 .

44. 405 F.2d 1082 (1968).

45. 405 F.2d at 1097 n.63. The cigarette case also provides a fascinating example of the Commission's flexible concept of controversy. On January 2, 1971, a congressionally imposed ban on television cigarette advertising became effective, 15 U.S.C. $\$ 1335$ (1970). Following this ban, the Commission ruled that although licensees would no longer be required to air the antismoking messages, they could air them if they wished, without incurring any obligations to present a prosmoking viewpoint. The basis of this ruling was the Commission's determination that the question of smoking was no longer controversial. Formulation of Appropriate Further Regulatory Policies Concerning Cigarette Advertising and Antismoking Presentations, 27 F.C.C.2d 453 (1970), aff'd sub nom. Larus \& Brother Co. v. FCC, 447 F.2d 876 (4th Cir. 1971). In Capital Broadcasting Co. v. Mitchell, 333 F. Supp. 582 (D.D.C. 1971) aff'd mem. sub nom., Capital Broadcast Co. v. Kleindienst, 92 S. Ct. 1289 (1972), a three judge court upheld the cigarette advertising ban against a first and fifth amendment challenge in a 2-1 decision, with Wright, Circuit Judge, dissenting. The dissent expressed concern over this exercise of government power to define what issues will be subject to public debate. Id. at 590, 592-93.

46. 24 F.C.C.2d 743 (1970), rev'd and remanded, Friends of the Earth v. FCC, 449 F.2d 1164 (D.C. Cir. 1971). 
But "[n]o one proposes to stop promoting or using the fruits of the technological revolution. . .."47 Third, advertising is only peripheral to the important pollution problems, whereas educational campaigns and restramts on promotion are central in the effort to reduce sinoking. ${ }^{48}$

Commissioner Johnson, dissenting, quoted the same Loevinger concurrence in the cigarette ruling he had earlier belittled; ${ }^{49}$ he now agreed with Commissioner Loevinger that the analogy between cigarettes and automobiles was strong. ${ }^{50}$ The D.C. Circuit, coming to the same realization, reversed the Commission a year later:

Commercials which continue to insinuate that the human personality finds greater fulfillment in the large car with the quick getaway do ... ventilate a point of view which not only has become controversial but involves an issue of public importance. When there is undisputed evidence, as there is here, that the hazards to health implicit in air pollution are enlarged and aggravated by sucli products, then the parallel with cigarette advertising is exact and the relevance of Banzhaf inescapable. ${ }^{51}$

Subsequent litigation has also failed to justify the distinction between cigarettes and other advertising. ${ }^{52}$

Sliglitly before the Circuit Court upset the unique product distinction, the Commission modified its position on applicability of the fairness doctrine to commercials by adding a "directness" standard. In Alan F. Neckritz, ${ }^{53}$ the coinplaint involved Clevron F-310 advertisements, then subject to a Federal Trade Commission complaint. ${ }^{54}$ The FCC rejected the complainant's contention that the advertisements were themselves the subject of controversy due to the FTC

47. 24 F.C.C. $2 d$ at 746.

48. Id. at 746-47.

49. See text accompanying notes 41-43 supra.

50. 24 F.C.C.2d at 753.

51. Friends of the Earth v. FCC, 449 F.2d at 1169.

52. In Retail Store Employees Local 880 v. F.C.C., 436 F.2d 248 (D.C. Cir. 1971) the court held that in considering a radio licensee's renewal application the Commission had given insufficient attention to the claim that the licensee had violated the fairness doctrine in limiting the Union's access to broadcast tinie to reply to conventional advertisements urging patronage of a store then subject to a union boycott. Id. at 255-56. But cf. Green v. FCC, 447 F.2d 323 (D.C. Cir. 1971) in which the same court was not persuaded to reverse the Commission's ruling in the case of military recruitment advertisements. The complainant wanted reply time to discuss alternatives to military service, but the court found that the issue was not raised by the recruitment advertisements, and that at any rate the question was not a controversial issue of public importance. Id. at 329-30. The Ninth Circuit reached a similar result in a brief, less complete opinion. Neckritz v. F.C.C., 446 F.2d 501 (9th Cir. 1971).

53. 29 F.C.C.2d 807 (1971).

54. Standard Oil Co. of California-Conılaint 3 Trade Reg. REP. $\uparrow 19,352$ at 21,485 (F.T.C. 1970). 
suit. $^{55}$ Further, the Commission held that although the advertisements made claims for the social utility of the product as an aid in fighting pollution, the commercials did not deal "directly" with a controversial issue. ${ }^{56}$ In adding this new standard of directness, ${ }^{57}$ the Commission admitted in a footnote that advertisements could deal directly with controversial issues, ${ }^{58}$ and that such advertisements would trigger the fairness doctrinc. The Commission provided an example shortly thereafter in the Alaskan pipeline case.59 Time was sought to reply to Standard Oil advertisements advocating the construction of the Alaskan pipeline, then the subject of heated debate concerning its environmental impact. Finding that the advertisement dealt directly with a controversial issue, the Commission held that the licensee had to ensure that the advertiseinents were balanced with anti-pipeline material..$^{00}$

With the state of the law thus confused, the Commission posted its Notice of Inquiry ${ }^{01}$ inviting comments directed at a full scale reexamination of the fairness doctrine. In the Notice the Commission reiterated its belief that most product commercials are distinguishable froin cigarette advertising and that the public interest would not be served by requiring licensees to provide free time to reply to most product commercials. Most of the filings with the Commission expressed the same viewpoint. ${ }^{62}$

The next section of this Comment tests this liypothesis by analyzing the issues raised by three categories of commercials.

\section{III}

\section{Three Categories of Commerctals}

\section{A. The Commercially Sponsored "Advertorial"}

Institutional advertising designed to convey a favorable image of an industry or corporation rather than to sell a particular product cannot be readily distinguished from other messages subject to fairness re-

55. 29 F.C.C. $2 d$ at $810-11$.

56. $1 d$. at 812 .

57. The Commission had previously implied the direetness standard in Friends of the Earth, 24 F.C.C.2d 743, 749 (1970).

58. 29 F.C.C.2d at 812 n.6.

59. National Broadcasting Co., 30 F.C.C.2d 643 (1971), rehearing sub nom. Wilderness Society, 31 F.C.C.2d 729 (1971).

60. But on rehearing, the Commission held that balance had been provided by other hicensee programming. See text accompanying notes 140-49 infra.

61. See note 11 supra.

62. Much of the opposition is based on the expectation that serious financial loss to the licensees will result; this concern is treated in part V. Materials submitted by the Federal Trade Commission and the National Citizens Committee for Broadcasting argue for continued expansion of the doctrine to commercials, however. 
quirements. When these commercials deal with controversial issues they are really sponsored editorials-the company has simply purchased time in which to express an opinion on a public issue. These sponsored editorials, recently called "advertorials", separate category from traditional advertisements.

Advertorial messages are controversial almost by definition; there is little question that they should trigger the fairness doctrine. The only difference between advertorials and normal editorials is the spokesman and perhaps also the motive. These differences are irrelevant to the doctrine. For example, one oil company has recently begun an advertising campaign to convey its concern with environmental problems. ${ }^{64}$ One advertisement proclaims the company's longstanding policy of never "willfully" polluting the nation's beaches. Another advertisement, showing people walking on a highway, portrays the campaign to reduce automobile use as absurd. One inight describe this company's advertising strategy as follows:

(1) Oil companies are getting a bad name because of recent oil spills and ecologists' attacks on the environmental inpact of their operations;

(2) further attention to these issues may result in either consumer behavior or governmental action that will decrease profits;

(3) therefore, these advertisennents are needed to persuade the public that no such action is necessary because the coinpany already conforms to all reasonable environmental requirements, and other proposed solutions are wildly impractical.

Profit is surely the coinpany's inotive, but the company clearly intends to influence the political process to maintain or increase profits. These television messages can be fairly characterized as political advertisements with a profit motive; it would be strange to shield the advertisenents from the fairness doctrine because of that motive.

The directness standard ${ }^{65}$ devised by the Commission may well have been aimed at distinguishing this kind of announcement, but if so

63. See Note, 85 HaRv. L. REv. 689-701 (1971). The Note coins this term in describing the antiwar messages prepared by the Business Executives' Move for Vietnam Peace. In that case an admittedly political group sought air time to present these unessages; the network turned the group down because of a policy of not accepting controversial advertising except in connection with elections. This is the saune network that sought to defend broadcasting of the Standard Oil pipeline advertisements from coming under the fairness doctrine. Obviously the only apparent distinction between these two sets of advertorials is the type of sponsor. The network policy against controversial advertisements was overturned in Business Executives' Move for Vietnam Peace v. FCC, 450 F.2d 642 (D.C. Cir. 1971), cert. granted 405 U.S. 953 (1972).

64. Brief for National Citizens Committee for Broadcasting at 6 \& appendix at 4 , in Notice of Inquiry, supra note 11.

65. See text accounpanying notes 56-60 supra. 
it is a poor tool. The directness standard could conceivably exempt from fairness requirements messages that differ only in the subtlety with which they argue their view. Yet a subtle form of persuasion may be used because it is believed to be more effective. Furthermore, it is not clear how the directness standard is employed or whether it really is the standard the Commission has used to distinguish advertorials from other kinds of advertiseinents. For instance, in $\mathrm{Na}$ tional Broadcasting Company, ${ }^{66}$ the Commission dealt with Standard Oil Company commercials similar to the oil company advertiseinents discussed above. The complainants had requested time to respond to three Standard Oil messages that they maintained raised two controversial issues concerning the Alaskan pipeline: ${ }^{67}$ the need to develop Alaskan oil reserves quickly and the feasibility of exploitation without environmental dainage. NBC defended on the grounds that the advertisements contained no explicit references to the proposed Alaskan pipeline but referred only to: (1) the investment of oil industry resources in searching out unknown oil deposits, a non-controversial issue; (2) the experience of Standard Oil's Canadian affiliate since its discovery of oil in the Canadian arctic; and (3) the Canadian affiliate's concern for preserving the arctic ecology. ${ }^{68}$ Noting that Standard Oil had simultaneously run a magazine advertiseinent dealing explicitly with the Alaskan pipeline issue, the Commission held that the television advertisements fell within the directness standard ${ }^{80}$ and thus constituted discussion of one side of a controversial issue of public importance.

Thus, the Alaskan pipeline case dealt with conmercials that never referred to the pipeline, yet were held to fall within the directness standard. ${ }^{70}$ The F-310 case, ${ }^{71}$ on the other hand, involved advertisements explicitly directed to the issue of air pollution, yet the advertisements did not ineet the directness standard. Thus, if directness is taken to mean explicit discussion of a controversial issue, then the standard

66. 30 F.C.C.2d 643, rehearing sub nom. Wilderness Socicty, 31 F.C.C.2d 729, reconsideration denied, 32 F.C.C.2d 714 (1971).

67. 30 F.C.C.2d 643-44.

68. 30 F.C.C.2d at 644 . The National Broadcasting Company also maintained that because it had a policy of not accepting commercial announcements dealing with controversial issues, these advertisements would not have been accepted had they been controversial. Approval of this policy by the FCC was upset in Business Executives' Move for Vietnam Peace v. FCC, 450 F.2d 642 (D.C. Cir. 1971) cert. granted 405 U.S. 953 (1972). NBC asserted, however, that the advertisements were simply "mstitutional advertising, seeking to create good will for the corporation as a whole and the general conduct of its enterprise." 30 F.C.C.2d at 644 .

69. Id. at 645-46.

70. "The matter is indeed a difficult one-because . . . the pipeline controversy is not specifically referred to . . ." 31 F.C.C.2d at 733 .

71. Alan F. Neckritz, 29 F.C.C.2d 807 (1971). 
does not adequately distinguish these two cases. The pipeline messages can better be distinguished from the F-310 advertisements by looking at the subject of the inessages. In F-310 the controversial claim related to the nature of the touted product, whereas in the pipeline case no product was involved. As discussed below, ${ }^{72}$ a strong argument can be made that certain claims relating to an advertised product should not be considered under the fairness doctrine. But institutional advertising conveying a controversial message cannot be distinguished from other opinion messages subject to fairness requirements. A pro-pipeline view should require balance whether it is made subtly or explicitly, or whether it is made by an oil company, the licensee in an editorial, or the company manufacturing the pipelines.

Although the Commission has not explicitly recognized a distinct category for advertorials, it apparently will continue to apply the fairness doctrine to them. In the recent case of Center for Auto Safety, ${ }^{73}$ for example, Ford Motor Company messages portraying air bags as coinplicated, costly and extreme were held to require a balancing view. ${ }^{74}$ The National Broadcasting Company argued that the subject of the messages was safety, the comments on air bags being merely incidental to the generally noncontroversial discussion. ${ }^{75}$ The Commission lield, however, that the air bag comments constituted a separate issue, that they were partisan in tone, ${ }^{76}$ and that they therefore triggered the fairness doctrine.

\section{B. The Controversial Product}

Advertisements may address themselves solely to the desirability of a product yet still be controversial because the very use of the product is a debated public issue. This was the heart of the Commission's ruling in the cigarette case. But as in Friends of the Earth, the Commission has been reluctant to expand this principle to other products. ${ }^{77}$ Retail Store Employees Local 880 v. F.C.C. exemplifies this reluctance. ${ }^{78}$ In that case, the union asked the Commission to

72. See text accompanying notes $96-113$ infra.

73. 32 F.C.C.2d 926 (1972).

74. Id. at $926,931$.

75. Id. at 927 .

76. Id. at 931 .

77. See text accompanying notes 40-52 supra.

78. 436 F.2d 248 (D.C. Cir. 1970). Although the complaint arose in the context of the broadcaster's (WREO) application for license renewal, the issue was the same. In considering the application the Commission is required to weigl the "public interest." 47 U.S.C. $§ 307$ (1970). Past compliance with the fairness doctrine is an important component of this judgment. "[W]e regard strict adherence to the fairness doctrine as the single most important requirement of operation in the public interest." Committee for Fair Broadcasting of Controversial Issues, 25 F.C.C.2d 283, 292 (1970). 
consider an alleged failure to meet fairness doctrine obligations arising from the presentation of standard commercials urging patronage of a department store under union boycott. The Retail Clerks Union sought to purchase spot announcements asking for cooperation in the boycott. The licensee carried the Union's announcements for a while, but ultimately refused to sell time to the Union, although it continued to carry the store's commercials. The Commission refused to consider the matter, apparently assuming that no fairness doctrine obligations could arise from the airing of such standard advertising fare. ${ }^{70}$

The D.C. Circuit ordered the Commission to consider the fairness doctrine question, however. ${ }^{80}$ Though patronage of a local department store was not an issue of national importance, as are the dangers of smoking or automobile air pollution, the court leeld that the issue was one of controversy and importance in the local service area of the broadcaster. The analogy to Banzhaf and Friends of the Earth was complete. In those cases, fairness doctrine obligations arose even though no health claims were explicitly presented in the cigarette advertisements, nor were environmental claims explicitly advanced in the automobile advertisements. There was no need to denonstrate that such claims were clearly expressed because the very behavior that those advertisements encouraged was controversial. The same is true of the behavior in Retail Stores: patronage of the struck department store.

The Retail Stores court bolstered its conclusion by referring to the national policy of evenhandedness in labor disputes. ${ }^{81}$ But national policy cannot be a controlling criterion or the government will be in the position of defining those subjects suitable for debate on the broadcast media ${ }^{82}$ Indeed, it may be the government's view that is

79. The summary nature of the Commission's ruling makes it impossible to determine its basis for rejecting the Union's request. Radio Enterprises of Ohio, Inc., 14 P \& F RADIO REG. 2d 780 (1968).

80. In the present case, it seems clear to us that the strike and the

Union boycott were controversial issues of substantial public importance within

Ashtabula, the locality primarily served by WREO. The ultimate issue with

regard to the boycott was simple: whether or not the public should patronize

Hill's Ashtabula. From April through December, Hill's broadcast over WREO more than a thousand spot announcements and more than one hundred sponsored programs explaining why .... the public should patronize the store. During that same period, the Union was denied an opportunity beyond a single roundtable broadcast to explain why ... the public should not patronize the store.

$436 \mathrm{~F} .2 \mathrm{~d}$ at 258.

81. Id. at 259 .

82. Such a governmentally approved list of controversial subjects might be constitutionally suspect. Red Lion Broadcasting Co. v. FCC, 395 U.S. 367, 396 (1969). See also the dissenting opinion of Judge Wright in Capital Broadcasting v. Mitchell, 333 F. Supp. 582 (D.D.C. 1971), affd mem. sub nom., Capital Broadcasting v. Kleindienst, 92 S. Ct. 1289 (1972). 
challenged, as was illustrated by three companion cases decided by the Commission in mid-1970.83 The cases involved military recruitment advertisements prepared by the Department of Defense. These messages obviously were not commercials in the conventional sense of the term. In fact, the licensees considered them public service announcements and donated the air time. ${ }^{84}$ But even though the Defense Department is not a profit making enterprise, its spot announcements are very similar to other advertisements discussed in this section. By urging young inen to join the army, the Defense Department may well be charged with selling a controversial product. ${ }^{85}$ The complainants, seeking time to reply, asserted that many people felt that the best way for a young man to handle his military obligation was to obtain a legal deferment; that service in the armed forces is not beneficial to either the individual or the society; and that the advertisements could not be considered apart from the Vietnam War because fighting wars is the main purpose of the armed forces, and any recruit was likely to find himself in Vietnam. ${ }^{86}$ The Commission denied time to the complainants, holding that the narrow issue of the government's right to raise an army is not controversial and that the broad issues of the Vietnam War and the draft were not raised by the advertisements. ${ }^{87}$

Commissioner Johnson, dissenting, pointed out that the Commission had ignored the contentions advanced by the complainants: "If the Commission had applied similar reasoning to cigarette advertise-

83. Women for Peace, 24 F.C.C.2d 156 (1970); Alan F. Neckritz, 24 F.C.C.2d 175 (1970), aff'd, 446 F.2d 501 (9th Cir. 1971); David C. Green, 24 F.C.C.2d 171 (1970), aff'd, 447 F.2d 323 (D.C. Cir. 1971).

84. 24 F.C.C.2d at 158.

85. In the alternative, the messages could be considered advertorials arguing the merits of a military life. An example of the spot announcements may prove helpful:

This is Frank Blair speaking to young men facing a military obligation.

As a father, I was pleased when my sons Thomas and John told me they wanted to become Marines. They told me that there was more than one way to look at an obligation: to consider it something you have to do, or as an opportunity to grow as an imdividual. How about you? Are you ready to develop in body, mind, and spirit? Find out the details from your Marine Corps representative today.

447 F.2d at 325 n.2.

None of the other advertisements alluded to the draft, [id. at 325], but they did portray army life as rewarding:

We understand you're looking for a man's job. Well, we just may have one. Who are we? We've been in business since 1775. We're located in close to 200 places around the world. We'll pay while we are training you. Give you thirty days off per year. Give you a chance to continue your education. And we'll build you a man. We'll build you a Marine. And that man and that Marine will be you. Ask a Marine.

24 F.C.C.2d at 161.

86. 24 F.C.C.2d at 156.

87. Id. at 157-58. 
ments three years ago. we would presumably have ruled that cigarette advertisements raise only the issue of whether cigarette advertisers have the right to recruit customers." 88 Rather, Johnson asserted, the cigarette advertisements were held to raise the controversial issue of whether smoking was desirable, just as the recruitment advertisements raised the issue of whether joining the army was desirable. ${ }^{80}$ And as the complainants stated, that question is controversial..$^{00}$ Furthermore, it is controversial at least partly because fighting wars is the function performed by the recruits. ${ }^{01}$

The Commission's decision was sustained, however, by the D.C. Circuit in Green v. FCC. ${ }^{02}$ The court agreed with the FCC that military recruitment by voluntary means was the only issue raised by the advertisements and that the government's right to recruit was not a controversial issue. ${ }^{93}$ The court held that the replies proposed by the coinplainants referred to the draft and to the Vietnam War and that those issues were not raised by the recruitment announceinents. To the complainants assertion that the issue presented was "whether military service was desirable, rewarding, or the best way to serve one's country," the court responded that "it is obvious that desirability

88. Id. at 163.

89. Id. at 161,164 .

90. Id. at 163-65.

91. The replies proposed by the complainants responded to the question of the desirability of volunteering for the armed forces either as a way of fulfilling one's "obligation" or because of the valuable opportunities presented to a recruit. They focused primarily on providing the information omitted from the recruitment announcements:

Attention all men of draft age. What are you planning to do about the draft? It is not generally known, but the selective service law does provide many deferments to which you may be entitled. If the army is not your bag, and you feel you may be eligible for deferment-do something about it now. Phone 642-1431 for information.

447 F.2d at 325 n.4. The Vietnam War was dealt with only insofar as it was important to a man's decision on whether to enlist:

Thinking about joining the army? Before you do, consider the facts. Chances are, the only job you'll learn is how to kill. Chances are, you'll wind up in Vietnam, killing and perhaps getting killed, in a war that doesn't make much sense. So if you're thinking about the military, remember this: you may be eligible for a military deferment. Id. at 326.

Commissioner Johnson also pointed out that the recruitment has created a deceptive mipression that required balance:

... [A] young man of draft age may have alternatives to the 'enlistor-be-drafted' dilemma. Congress itself has ... exempted from military service .... persons who fall in numerous categories. Persons, therefore, whom Congress did not intend to induct, may be induced into a military obligation which was unrequired, and perhaps even undesirable, as a direct Id. at 166 .

consequence of partial truths contained in the advertisements before us.

92. 447 F.2d 323 (D.C. Cir. 1971).

93. Id. at 329. 
or undesirability of military service comes right back to the draft and the Vietnam war." 94 Thus the petitioners lost both ways-the court read the recruitment advertisement narrowly but read the anti-recruitment advertisements broadly.

The sensitive political nature of this controversy may liave motivated both the Commission and the courts. It is otherwise difficult to explain their conclusion that the recruitment messages do not argue that joining the army is desirable. Nonetheless, this case should not signal a serious departure from the trend evidenced by Banzhaf and Friends of the Earth, for the essence of the court's ruling was that the message did not raise the issue the complainants had been concerned with. ${ }^{95}$ The principle remains that an advertisement may trigger the fairness doctrine because use of the touted product is itself controversial. The outcome in Green may perhaps be best explained as the result of reluctance of both the Commission and the court to take any action that could be characterized as challenging the government's ability to effectively wage war.

\section{Deceptive Advertising}

A third broad category that has received recent Commission attention comprises advertisements alleged to be deceptive. Such deception may result from statements that are untrue or incomplete, and the deception may concern the relation of the product to an important social issue. But the defining characteristic of these advertisements is that the deception concerns the nature of the advertised product itself. Thus, misleading statements such as those alleged to have been made in the Alaskan pipeline messages would not be in this category.

The potential breadth of this category is demonstrated by a recent petition filed with the Commission by a group of law students calling themselves Termination of Unfair Broadcasting Excesses (TUBE). ${ }^{96}$ The group asked the Commission to consider new rules setting out specific obligations of licensees to deny broadcast time to deceptive advertisements. ${ }^{97}$ TUBE provided twenty examples of advertisements it considered deceptive, ${ }^{98}$ mcluding commercials for:

(1) Toys (e.g., a doll is photographed in a manner calculated to create the impression of a greater variety of movements than it actually has);

94. Id. at 331.

95. The court also held that even if complainants definition of the issue were accepted coverage of contrasting views on the draft and the war had beeu adequate. Id. at 330.

96. Adoption of Standards Designed to Eliminate Deceptive Advertising from Television, 32 F.C.C.2d 360 (1971).

97. Id. at 396.

98. Id. at 391-96. 
(2) Analgesics (e.g., a brand of aspirin is advertised as relieving tension when studies show that it does not);

(3) Household goods (e.g., a vegetable slicer is portrayed as cutting and shicing easily when in fact it is difficult to use);

(4) Enzyme detergents (numerous advertisements fail to disclose that lengthy presoaking is required, that only certain stains are susceptible to enzyme treatment, and that the enzymes may eat holes into the fabric.)

In declining to adopt the TUBE proposal, the Commission reiterated its general policy of holding hicensees responsible to "take all reasonable measures" to eliminate false, misleading, or deceptive matter. ${ }^{99}$ In a companion case to TUBE, ${ }^{100}$ the Commission rejected the suggestion that licensees be required to maintain a staff witl the skills and facilities needed to make an independent assessment of an advertiser's claims. The licensee is required only to make a commonsense judgment regarding a proferred advertisement. ${ }^{101}$ If an advertiseinent is the subject of a Federal Trade Commission complaint, however, the licensee is cautioned to exercise particular care in airing it. ${ }^{102}$

Further, the FCC itself will not attempt to determine if a particular advertisement is false or misleading, except possibly in "flagrant" cases. ${ }^{103}$ The FCC explains this policy in terms of deference to the Federal Trade Commission's greater expertise with this subject. ${ }^{104}$ The FTC has in fact begun a new cainpaign requiring some advertisers to air messages correcting the misleading impressions created by prior commercials. ${ }^{105}$ Nevertheless, the TUBE petition strongly argues that FTC regulation of deceptive advertisements is inadequate..$^{108}$

The issue is not, however, whether the FTC or the FCC could control deceptive advertising more effectively, but rather whether the fairness doctrine is an appropriate tool for this purpose. Although

99. Id. at 361 .

100. Consumers Association of District of Columbia, 32 F.C.C.2d 400 (1971). See also Action for Children's Television, 32 F.C.C.2d 412 (1971).

101. Consumers Association of the District of Columbia, 32 F.C.C.2d 400, 406 (1971).

102. The broadcast of a commercial known to have been the subject of an FTC order would raise "serious questions" as to the adequacy of the measures instituted by the bicensee in fulfillment of his responsibility. 32 F.C.C.2d 360, 361.

103. 32 F.C.C. $2 \mathrm{~d} 400$ at 405.

104. Id. at 404-05.

105. See Note, Corrective Advertising and the F.T.C., 70 MICH. L. REv. 374 (1971). See also, Profile Bread's Well Buttered Correction, 37 Consumer Reports, February 1972, at 37.

106. 32 F.C.C. $2 \mathrm{~d}$ at $363-64$. 
the TUBE petition did not request fairness doctrine treatment of misleading product claims by advertisers, such a request was made in the F-310 case, ${ }^{107}$ in which the disputed claim concerned the value of the product for reducing automobile-caused air pollution. ${ }^{108}$ Commissioner Johnson, dissenting from the Commission's decision not to apply the fairness doctrine to the F-310 Advertisements, claimed that they "practically shout" that they are dealing with a controversial issue of public importance. ${ }^{109}$ In one sense he is right; the advertisements are clearly concerned with an important and controversial subject. But as the Commission majority point out, the advertisements do not take a position on air pollution-they do not claim that it presents no danger or that automobiles are not a chief cause of it. They merely claim that their product reduces polluting exhaust emissions, and it was this claim that the F-310 complainants wished to challenge. ${ }^{110}$ In support of their argument that the utility of F-310 was a debated public issue, the complainants pointed to the pending FTC complaint against Chevron that alleged that the claims made for F-310 were false and misleading. ${ }^{111}$

The basic issue in $F-310$ is similar to that presented by an advertisement portraying a vegetable slicer as an effective, durable kitchen utensil. The advertiser's claims for his product are either deceptive or they are not. If the claims are true, there is no social benefit to be gained from allowing others to argue against them. If they are false, the proper course is not to make the claims the subject of broadcast debate, but rather to ban the advertisement altogether.

Though this remedy already exists in the form of Federal Trade Commission cease and desist orders, many have argued that for vari-

107. Alan F. Neckritz, 29 F.C.C.2d 807 (1971). This case is discussed in detail by the complainant in Comment, Ecological Pornography and the Mass Media, 1 ECOL. L.Q. 374 (1971).

108. Indeed, the F-310 advertisements deliberately played upon consumer concern over this important public issue:

Now Standard Oil of California has accomplished the development of a remarkable gasoline additive, Fornula F-310, that reduces exhaust emissions from dirty engines. The same car, after just six tankfuls of Chevron with F-310; no dirty smoke, cleaner air. A najor breakthrough to help solve some of today's critical problems. . . C Cleaner air, better mileage. . . .

29 F.C.C. $2 \mathrm{~d}$ at 807 . Or:

I'in sure you're as concerned as I am about the problems of controlling our environment. And one of the most critical is the need for cleaner air. ... These are some of the important steps Standard Oil has taken toward solving a growing national problem. Use Chevron gasolines with F-310. You'll be doing your part toward cleaner air. Scott Carpenter for Standard Oil.

Id. at 817.

109. Id.

110. Id. at 812 .

111. Id. at 816 . 
ous reasons the FTC is unable to use this power effectively. ${ }^{112}$ Indeed, the FTC has offered this as one reason why the FCC should aid in the battle by extending the fairness doctrine to deceptive advertisements. ${ }^{113}$ But this proposal trivializes the fairness doctrine and detracts attention from efforts to strengthen its effectiveness in promoting public debate over important national and local issues. To require broadcasters to consider fairness doctrine requests to debunk the value of a vegetable shicer on an equal footing with requests to discuss foreign policy or community efforts to deal with drug abuse problems would needlessly overburden the Commission and its licensees. Furthermore, there are economic reasons for not including deceptive commercials in the fairness doctrine. As discussed in Section V, requiring broadcasters to provide increascd amounts of free time to people wanting to respond to commercials can create serious economic difficulties for the station owner. It is both reasonable and necessary for the Commission to set priorities limiting the categories of commercials that should be included in the fairness doctrine in order to protect licensees from undue financial burdens. Deceptive advertisements present the weakest argunent for inclusion under the fairness doctrine and thus have the lowest priority.

IV

\section{Determining BALANCE}

A layman would have no difficulty with this case under the popular understanding of the fairness doctrine. He would simply say that fairness means that each side gets the same treatment. But the fairness doctrine does not stand for any such simplistic proposition . . . . ${ }^{114}$

\section{A. Personal Attacks and Political Programs}

Unlike the statutory equal time provision, ${ }^{115}$ the fairness doctrine does not require rigidly equal treatinent of conflicting views. What it requires is "a balanced presentation," and the determination of what constitutes balance is left largely to the discretion of the licensee. Chairman Burch has warned of the chaos that would result from Commission intrusion into this determination ${ }^{116}$ and both he and the

112. See generally E.F. Cox, R. Fellmeth \& J. Schultz, REPORT ON THE FEDERAL Trade Commission (1969).

113. FTC Brief in Notice of Inquiry, supra note 11, at 7-11.

114. Wilderness Society, 31 F.C.C.2d 729, 735 (1971) (Chairman Burch, concurring).

115. 47 U.S.C. \& 315 (1970).

116. Wilderness Society, 31 F.C.C.2d 729, 734 (1971). 
Commission have said that requiring rigidly equal treatment would frustrate the fairness doctrine by choking the airways with uninformative replies and counter replies. ${ }^{117}$

Despite these pitfalls, the Commission has nevertheless imposed on licensees its own conceptions of balance for two kinds of messages: personal attacks on individuals, and political broadcasts favoring one candidate in an election. When an attack is made on "the honesty, character, integrity, or like personal qualities of an identified person or group" a regulation requires the licensee to notify the individual or group within one week of the broadcast. ${ }^{118}$ The notification must include a script or tape of the attack ${ }^{119}$ and an offer to respond to it over the licensee's facilities. The same regulation also applies when a licensee endorses or opposes a legally qualified candidate for public office. ${ }^{120}$ The licensee must then provide the required notification to opposed or non-endorsed candidates within 24 lours.

In effect, both these rules limit licensee discretion to choose a spokesman or to control his presentation. The person attacked or the non-endorsed candidate is guaranteed personal access to the licensee's facilities. In upliolding these rules, the Supreme Court in Red Lion viewed them as a reasonable outgrowth of the fairness doctrine. ${ }^{121}$

The Commission has come close to imposing similar requirements in other political cases. In Nicholas Zapple, ${ }^{122}$ responding to a letter posing two fairness doctrine hypơtheticals, the Commission concluded that the fairness doctrine would apply if a committee supporting a candidate bought television time to solicit votes or campaign funds, although the statutory equal time provision would not apply to the broadcasts if the candidate did not appear. The Commission leld that under the fairness doctrine it would be unreasonable, absent unusual circumstances, for a licensee to refuse to sell time to the spokesinen for the other candidate since they would be the logical proponents of the opposing viewpoint. ${ }^{123}$ And in Committee for Fair Broadcasting of Controversial Issues, ${ }^{124}$ the Commission found that after the President

117. Id. at 738; Committee for Fair Broadcasting of Controversial Issues, 25 F.C.C.2d 283, 292 (1970).

118. 47 C.F.R. $\S \S 73.123,73.300,73.598,73.679$ (1971) (all identical).

Id.

119. A summary may be provided if a script or transcript is not available.

120. Id.

121. Red Lion Broadcasting Co. v. FCC, 395 U.S. 367 at 385-86 (1969). The Court noted that "the objective of adequate presentation of all sides may best be served by allowing those most closely affected to make the response, rather than leaving the response in the hands of the station which has attacked their candidacies, endorsed their opponents, or carried a personal attack upon them." Id. at 379.

122. 23 F.C.C.2d 707 (1970).

123. Id. at 708 .

124. 25 F.C.C.2d 283 (1970). 
had resorted to national television five times in seven months to speak on the Vietnam War, the fairness doctrine required that Congressional spokesinen for the opposition also have the opportunity to address the nation directly. Coverage of the opposing views on news programs alone was inadequate to balance the national television time given the President. ${ }^{125}$

Although Chairman Burch has referred to Zapple and Fair Broadcasting as creating a "quasi-equal opportunities approach" to political broadcasts, ${ }^{126}$ these cases and the personal attack and political editorial rules deal with only one aspect of equality. They require that the leading spokesman for the opposing viewpoint have "direct access" to the media for the fairness doctrine to be satisfied, whereas in most situations the licensee may meet his fairness obligations by having a third party, such as a newscaster, explain the opposing view. Although "direct access" is undoubtedly important, other considerations should also go imto a determination of balance.

These additional components of balance should include: the total amount of time allowed for the presentation of each view; whether the form of the reply time will be in a few relatively large blocks of time, or in a larger number of brief spot announcements; and finally, the nature of the audience that may be expected. The last criterion usually resolves itself into the question of prime versus non-prime time presentation, the distinction being important primarily because of varying audience size. Composition of the audience varies too, however; certain time periods may be inore likely to reach an audience with a high proportion of particular age groups of socio-economic classes.

Recognizing the importance of these additional criteria as ineasures of the impact of reply time, the Commission has overturned several licensee determinations of the annount and form of time necessary to balance political editorials. In the companion cases of George Cooley ${ }^{127}$ and Clarence Massart, ${ }^{128}$ the Commission informed the licensee: ${ }^{129}$

In scheduling 24 brief editorials in which five candidates are endorsed, you apparently made a judgment that your broadcast time can be inost effectively used by frequent repetition of a brief statement rather than by less frequent broadcasts of longer statements of reasons for your endorsement. Complainant seeks to avail himself of a comparable opportunity . . . . From materials submitted to us it does not appear that the offer of six announcements con-

125. Id. at 297-98.

126. Wilderness Society, 31 F.C.C.2d 729, 735 (1971).

127. 10 F.C.C.2d 969, reconsideration denied, 10 F.C.C.2d 970 (1967).

128. 10 F.C.C.2d 968 (1967).

129. Id. at 969 . 
stitutes reasonable opportunity for response to your 24 editorials and that you have not fully complied with the fairness doctrine.

The Commission also noted that the licensee did not specify the broadcast times for the complainant's 1-minute replies, or whether the potential audience during the reply time periods was comparable to the audience during the original announcements. ${ }^{130}$

It thus appears that the Commission has held or implied that proper balance requires relative equality in amount of time, potential audience size and form of the time; proper balance may also mean that occasionally particular spokesmen must be given direct access to broadcast time. None of these criteria seems difficult to administer or enforce, and they all are reasonable components of a balance requirement. Nevertheless, the Commission lias been hesitant to apply them to other than political programming. This reluctance is highlighted in fairness doctrime cases dealing with commercials.

\section{B. Commercials}

Advertisements always provide the purchaser with direct access, usually through frequent spot announcements at least some of which may be aired in prime time. Ruling on cigarette advertisements, the Commission had to determine proper balance for commercials for the first time. It concluded that anti-smoking views must be presented regularly via frequent spot announcement: ${ }^{131}$

We think that the frequency of the presentation of one side of the controversy is a factor appropriately to be considered in our administration of the Fairness Doctrine .... . For, while the Fairness Doctrine does not contemplate "equal time", if the presentation of one side of the issue is on a regular contimual basis, fairness and the right of the public to be adequately informed compels the conclusion that there must be some regularity in the presentation of the otler side of the issue.

But "regularity" is susceptible to varying definitions, and the Commission ultimately concluded that a five-to-one ratio of prosmoking to anti-smoking messages would be satisfactory. ${ }^{132}$ In a series of rulings ${ }^{133}$ the Commission considered the problem of maintaining a balance of prime time airings of the two views on smoking.

130. Id. at 968 .

131. 9 F.C.C.2d at 941.

132. National Broadcasting Co., 16 F.C.C.2d 956 (1969). In minutes of exposure the approved ratio was 5.6:1. The licensee actually aired 8 times as many cigarette announcements, however. Id. at 958 .

133. Chromicle Publishing Co., 15 P \& F Radlo REg. 2d 1020 (1969); Westinghouse Broadcasting Co., 15 P \& F RADIo REg. 2d 1059 (1969); National Broadcasting Co., 16 F.C.C.2d 956 (1969). 
Although some reasonable ratio would have to be maintained, the Commission concluded that parity between pro and anti-cigarette commercials during prime time should not be required because cigarette commercials would be driven off the air. ${ }^{134}$ The Commission did, however, reject as imadequate prime time ratios of $37: 1$ and $15: 1 .^{135}$ But in refusing to require more nearly equal exposure, a measure of mequity was built into the application of the fairness doctrine to commercial announcements.

When it affirmed the cigarette ruling, the D. C. Circuit also approved the Commission's refusal to require equal time for anti-smoking messages. ${ }^{138}$ The court noted, however, the importance of ensuring frequent presentation of the anti-smoking view, agreeing that proper balance to cigarette commercials required frequent anti-cigarette spot announcements. "A man who hears a hundred yeses for each no when the actual odds he the other way, cannot be realistically deemed adequately informed."137 The court considered the issue again in Retail Store Employees. ${ }^{138}$ The broadcaster argued that the sale of time to the Union for spot announcements would provide little additional public enlightenment; spot announcements tend to be repetitive and do not provide thorough coverage. Yet as the court pointed out, the spot format reaches a wider audience than an equivalent amount of time in a single block, and this may be valuable even at the risk of boring some listeners. ${ }^{139}$ Furthermore, regardless of the actual merits of spot versus block programming, the commercial advertisers by their own behavior testify to their belief that the spot nessage technique is more effective, and they have continued access to the spot message. Fair presentation requires that the other side have such access also, as was recognized in the cigarette case and in Retail Store Employees.

Despite these precedents, the Commission has indicated a strong reluctance to nuaintain an equal opportunity approach. In National Broadcasting Company ${ }^{140}$ the Commission initially determined that the Standard Oil pro-pipeline advertisements required additional balance under the fairness doctrine. ${ }^{141}$ On rehearing, the environmen-

134. 16 F.C.C.2d at 956.

135. Westinghouse Broadcasting Co., 15 P \& F Radro Reg. 2d 1059 (1969).

136. 405 F.2d at 1103. The plaintiff, John Banzhaf, never seriously helieved the court would require equal time. He appealed this issue only because it was the only one he had lost before the Commission. Banzhaf wished to appeal before the cigarette companies in order to be able to choose the forum. Whiteside, Annals of Advertising, THE New YORKER, Dec. 19, 1970, at 42.

137. 405 F.2d at 1099.

138. Retail Store Employees Local 880 v. FCC, 436 F.2d 248 (1970).

139. Id. at 257-58.

140. 30 F.C.C.2d 643 (1971).

141. See text accompanying notes 66-69 supra. 
talists requested that the Commission require the licensee to air their anti-pipeline spot announcements im number equal to the Standard Oil messages. ${ }^{142}$ They also noted that the Standard Oil advertisements were broadcast during Meet The Press, a program viewed by "an especially large number of decision makers," ${ }^{143}$ and asked that the replies be scheduled so that they would reach an audience of similar composition. Thus the Commission was asked to consider the four basic components of balance: amount of time, form of time, nature of the audience that may be expected, and direct access.

The Commission upheld a balance determination by the licensee that fell short of equality by each of these standards. Apparently viewing the task of defiming the requirements of balance as too difficult, the Commission retreated into the realm of licensee discretion. ${ }^{144}$ No atteinpt was even made to analyze the components of balance or to provide guidance as to how a proper determination should be made. The Commission upheld NBC's claim that additional anti-pipeline material, aired in a public affairs program and $\mathrm{m}$ an interview on the Today show, satisfied the fairness doctrine. ${ }^{145}$

Commissioner Johnson, dissenting, pointed out the inequity of the decision. $^{146}$ First, the additional material still left the pro-pipeline view with a 2:1 advantage in minutes of exposure when all of NBC's programming was considered. Secondly, 28 minutes of the pro-pipeline view were Standard Oil spot advertisements, while none of the anti-pipeline material was in spot announcement form. Thirdly, the Today sliow presentation was in interview format, while the Standard Oil advertisements allowed pro-pipeline interests to control the presentation of their views. Johnson questioned whether the licensee satisfied its fairness doctrine obligations "by balancing this spot advertising campaign with an interview program controlled and directed by a third party."147 Chairman Burch, concurring, admitted that some remedial action would be required under the "quasi-equal opportunities" approach used in political broadcasts. ${ }^{148}$ Yet without explanation lie assumed that this case should be treated differently. ${ }^{149}$

142. Wilderness Society, 31 F.C.C.2d 729 (1971).

143. 30 F.C.C.2d at 644 .

144. 31 F.C.C.2d at 733. See also Request for Rehearing, 32 F.C.C.2d 714 (1971).

145. 31 F.C.C.2d at 733.

146. Id. at $740-41$.

147. Id. at 742 .

148. Id. at 735 .

149. In an earlier case, Commissioner Johnson, in dissent, pleaded that he did not have "the slightest idea" how the majority arrived at its notion of balance. National Broadcasting Co., 16 F.C.C.2d 956, 961 (1969). 
There is really little reason to allow such broad licensee control over fairness doctrine decisions. It must be remembered that at this point in the pipeline case it had already been determined that a controversial issue of public importance was unfairly presented by the licensee. It was not unreasonable for the aggrieved party to expect closer Commission review of this licensee's actions. Moreover, there is no basis for distinguishing such cases froin "political" broadcasts. There is no licensee imterest to protect that is not also present in political cases, and the public interest in fair presentation seems identical. Perhaps, im view of the fact that the editorial rule and Zapple deal with elections, the Commission is creating some form of hierarchy that ranks the public interest in fair coverage of elections above the interest in fair coverage of important issues. If so, no explanation has been provided for such an ordering. Furthermore, in Fair Broadcasting, ${ }^{150}$ the Commission was concerned not with elections but with the expression of Presidential views on the Viet Nam War. The Commission argued that intensive use of television by the President made direct access for opposition spokesinen necessary to achieve balance. ${ }^{181}$ Again, though, no effort was inade to explain why the imbalance in Fair Broadcasting was more harmful to the public interest than the imbalance in the pipeline case, although it may be that the war issue was considered more important, or the imbalance more extreme.

The Commission could prevent this kind of disparity without adopting a rigid set of rules eliminating all licensee discretion. By breaking down the concept of balance into more clearly defined components, Commission guidance, apphicable to all fairness doctrine cases, could be given. The most severe limitations on licensee discretion should be placed on the decisions about reply broadcast format. Licensees should be obligated to balance direct access programming with other direct access programming. Spokesmen should also be able to choose the spot message technique if the opposing spokesmen have used this tool. No public interest is served by allowing licensees to permit only one party to a controversy to present its views directly via spot messages. The D.C. Circuit took this position when it reversed Commission approval of licensee imposed bans on controversial spot advertisements. ${ }^{152}$ Noting that the first amendment protects an individual's interest in expressing his ideas in his own

150. See text accompanying notes 124-25 supra.

151. 25 F.C.C.2d at 296-97.

152. Business Executives' Move for Vietnam Peace v. FCC, 450 F.2d 642, 655-56 (1971), cert. granted, 405 U.S. 953 (1972). The licensees at one time maintained that they allowed no one to use spot messages to advocate controversial positions, except as part of election campaigns. It was under this policy that they refused to sell time for antiwar messages. Id. at 647-48 n.5. 
way, ${ }^{153}$ the court concluded that speakers as well as listeners have rights on the broadcast media and the first amendment requires broadcasters to open up the airwaves for self-initiated and self-controlled expression. ${ }^{104}$

When advocates opposing the views presented in commercial an nouncements request time to air their own spot messages, they are asking only for the same right to self-initiated, self-controlled expression that commercial advertisers have. Both the D.C. Circuit ${ }^{155}$ and the 7th Circuit ${ }^{156}$ have recognized that individual style and intensity of feeling are important elements of debate which deserve constitutional protection. If the Constitution requires that broadcasters allow self-controlled expression, it must also require that the right be provided to all parties on an equal basis. Licensees cannot consistently favor one group-commercial advertisers-over those who seek to express opposing views.

There is a stronger basis, however, for maintaining greater licensee flexibility in regard to the other components of balance: length of exposure and audience composition. It would be difficult to set clear standards of equality for either criterion. For example, there is really no way to conclusively determine whether a spot message during Meet The Press is of equal value to one during the evening news program, or if a message aired on afternoon television is equal im value to one during an early morning show. Some weight inight also reasonably be given to other hicensee coverage of various views on the issue, mcluding news clips, documentary programming and interviews, that may be shown at varying times. If such coverage favored one view, it may be reasonable to provide the other view with something less than precisely equal time for spot messages.

Licensees have, of course, a legitimate interest in retaining some control over their scheduling. The licensee might for a variety of

153. Id. at 655 .

154. Even if broadcasters were to succeed in presenting a full spectrum of viewpoints and partisan spokesmen on non-advertised time, their retention of total initiative and editorial control is inimical to the First Amendnent. The importance of fair, objcctive and full treatment of controversial issues on normal programming cannot be doubted. But as the Supreme Court has said in the context of classrooln debate "supervised and ordained discussion" is not enough [citations omitted] ... In other words, there is always a strong First Amendment interest in opening up channels for more spontaneous, self-initiated, self-controlled expression.

Id. at 656 .

155. Id.

156. Lee v. Bd. of Regents, 306 F. Supp. 1097 (W.D. Wis. 1969), aff'd 441 F.2d 1257 (1971). The court held that the first amendment obliged a school newspaper to primt antiwar advertising. Antiwar views were primted in news columns and letters to the editor, but the court stressed the qualitative difference in the writers' control over the presentation in an advertisement. $306 \mathrm{~F}$. Supp. at 1101. 
reasons conclude that it would be more convenient to provide one view with slightly fewer total minutes of exposure, but slightly more minutes of prime time. Although fair presentation is more important than hicensee convenience, whether fair presentation would be protected by such an arrangement would depend on the particular circumstances.

The Commission could guard against abuse of licensee discretion by its allocation of the burden of persuasion in fairness doctrine proceedings. That burden should shift to the licensee whenever a cursory investigation reveals substantial differences in the scheduling of presentations and in the amount of time allocated to different views.

It is thus apparent that the Commission can adopt nnore explicit standards of balance which will more effectively ensure fair presentation without resulting in difficult administrative burdens or injury to other imterests. ${ }^{157}$

\section{V}

\section{CAN THE LICENSEES AfBord FAIRNESS?}

Under the Cullman primciple, ${ }^{158}$ a licensee unable to find a paying spokesman for an underrepresented viewpoint inust offer free time if necessary to achieve balance. This requirement obviously imposes a financial burden upon the licensees, but the Commission lias held that "it is clear that the public's paramount right to hear opposing views on controversial issues of public importance cannot be nullified by ... the inability of the licensee to obtain paid sponsorship of the broadcast time ....."150

Any broadening of the fairness doctrine thus carries with it the potential for increased financial burdens on the licensees. Witl respect to cominercial messages, an additional argument has been made: advertisers will shift their buying to the nonregulated nedia im order to avoid providing their adversaries with broadcast time. ${ }^{100}$ Though opposing groups could purchase space in the print inedia as well, they have potential free access only in television and radio.

In analyzing this econormic argument, it is important to distinguish between the first two categories of commercial announcementsthe commercially sponsored advertorial and the advertisement for a

157. Chairman Burch has himself complained of the absence of standards. Concurring in the Commission decision im the pipeline case, he observed that "after 20 years of administration" of the fairness doctrime, past Commission precedents say "virtually nothing." 31 F.C.C.2d at 736.

158. Cullman Broadcasting Co., 40 F.C.C. 576 (1963).

159. Id. at 577.

160. Brief for Columbia Broadcasting System, in Heading III of Notice of Inquiry, supra note 12, at 19-23. 
controversial product. ${ }^{161}$ Including advertorials within the fairness doctrine does not present the economic threat to licensees supposedly posed by the Banzhaf/Friends of the Earth rule ${ }^{\mathbf{1 6 2}}$ applying to advertisements for controversial products. Under Banzhaf, any cigarette commercial created fairness doctrine obligations, and the logic of the decision could extend to many other products. After Banzhaf, licensees predicted a "parade of horribles"163 in which advertisements accounting for a quarter of their revenue would trigger fairness doctrine obligations. ${ }^{164}$ Advertorials, however, represent a relatively minor portion of commercially purcliased time, and licensees can set a limit on the number they will accept. ${ }^{165}$ Furthermore, companies that have previously bouglit time for advertorials might replace those messages with conventional advertising, leaving broadcast revenues unaffected. For example, after Center for Auto Safety, ${ }^{168}$ Ford Motor Coinpany could avoid triggering the fairness doctrine by purchasing the same broadcast time and merely eliminating attacks on air bags from its commercials. This clioice, lowever, is not open to the advertiser of a controversial product successfully challenged under the Banzhaf/Friends of the Earth rationale. According to Friends of the Earth, any advertisement for a large automobile would trigger the fairness doctrine. ${ }^{167}$ Thus all advertisements for a controversial product necessarily trigger the doctrine.

The economic argument is of major importance, therefore, only when considering the extension of the fairness doctrine to advertisements for controversial products. The Commission dealt with the argument in the cigarette case by assuring licensees that there would be no extension of the principle to other products. ${ }^{168}$ But the Commission also indicated skepticism that the cigarette companies, which accounted for 7.2 percent of all 1966 television advertising revenues, would desert the licensees. ${ }^{162}$ As a concession to their concern, the

161. See text accompanying notes $64-95$ supra.

162. See text accompanying notes $35-45$ supra.

163. 9 F.C.C. $2 d$ at $942-43$.

164. See text accompanying notes 176-79 infra.

165. In Bnsiness Executives' Move for Vietnam Peace v. FCC, 450 F.2d 642 (D.C. Cir. 1971), the conrt held that broadcasters must accept some advertorials, but it carefully pointed ont that broadcasters could retain discretion to limit the number. Id. at 664 .

166. See text accompanying notes 73-76 supra.

167. See text accompanying notes $46-51$ supra.

168. 9 F.C.C. $2 d$ at $943-44$.

169. Id. at 944 n.26. The Commission said:

The attractiveness of the broadcast media, particularly television, as a means of effectively reaching the vast majority of the American public with advertising ... is witlout equal. We find it difficult to believe that cigarette advertisers would abandon or make substantially less use of a medium of this 
Commission promised the licensees that the ruling would be tailored so as not to curtail cigarette advertising. ${ }^{170}$ As a result, the Commission ultimately decided that licensees would be required to air anti-smoking messages only in a 1:5 ratio with cigarette commercials. ${ }^{171}$

Whether because of this tailoring or not, cigarette advertising did not decline significantly after the cigarette ruling. ${ }^{172}$ Nonetheless, the Commission relied on the economic argument as justification for its reluctance to extend the cigarette ruling to other products. In Friends of the Earth, it found the threat to the "commercial base" of television sufficient to bar extension of the cigarette ruling even if the coinplainants' arguments were accepted. ${ }^{178}$ In $F-310$, the Commission repudiated its earlier conclusion that extension of the fairness doctrine would not drive advertisers away. ${ }^{174}$ In none of these cases, however, has the economic arguinent been supported by specific facts and figures.

The economic issue was raised again in the Notice of Inquiry. ${ }^{175}$ The Columbia Broadcasting Systen's brief for Heading III of the Notice $e^{176}$ was desigued to provide a factual foundation for this notion of impending financial catastrophe. CBS presumes that the Banzhaf rationale, if not disowned by the Commission, will apply to cereals,

nature merely because our ruling may require an increase in the programmiug

on the smoking-health issue. ... .

(citations omitted). Id. at 944 .

170. Id. at 944.

171. National Broadcasting Co., 16 F.C.C.2d 947 (1967).

172. Reconsideration of the cigarette ruling was denied by the Commission in September, 1967. Applicability of the Fairness Doctrine to Cigarette Advertising, 9 F.C.C.2d 921. The first full year following the ruling was therefore 1968; the last year during which cigarette advertising was allowed was 1970 . 15 U.S.C. $\S 1335$ (1970). The following chart indicates the relative importance of cigarette advertising from 1965 through 1970 :

\begin{tabular}{cccc} 
Year & $\begin{array}{c}\text { Total T.V. Advertising } \\
\text { Expenditures (Thousands) }\end{array}$ & $\begin{array}{c}\text { Cigarette Advertising } \\
\text { Expenditures (Thousands) }\end{array}$ & $\begin{array}{c}\text { Cigarettes } \\
\text { As \% of Total }\end{array}$ \\
\hline 1965 & $\$ 2,335,820$ & $\$ 172,055$ & $7.4 \%$ \\
1966 & $2,600,639$ & 194,079 & 7.5 \\
1967 & $2,693,882$ & 216,569 & 8.0 \\
1968 & $2,823,852$ & 196,077 & 6.9 \\
1969 & $2,812,866$ & 201,847 & 7.2 \\
1970 & $3,034,333$ & 195,216 & 6.4
\end{tabular}

Source: Personal correspondence, Television Bureau of Advertising

Thus, cigarette advertising, in dollars, rose from 1965 to 1967; following Banzhaf it stabilized at an amount between that of 1966 and the high year of 1967. Therefore Banzliaf could be said, at most, to have stunted possible growth of cigarette advertising; by no means did the cigarette companies desert the mediun.

173. 24 F.C.C. $2 \mathrm{~d}$ at $748-49$.

174. 29 F.C.C.2d at 812 .

175. See note 11 supra.

176. See note 12 supra. 
gasoline and oil, drugs, and detergents. ${ }^{177}$ The three networks received $\$ 340$ million from these advertisers in 1970, accounting for 26 percent of all advertising revenues. ${ }^{178}$ Assuming that balance will be required for all commercials for these products, and figuring that a 1:5 ratio would be required, as in the cigarette case, the network reasons that advertising time worth $\$ 68$ million would have to be donated by the networks. Since the total pretax earnings of the three networks was only $\$ 50$ million in 1970, CBS concludes that under a broadened Banzhaf rule bankruptcy is inevitable. ${ }^{178}$ Finally, CBS argues that advertisers will flee to other inedia rather than subject their advertisements to replies.

To take the last arguinent first, the network neglects to point out that the only empirical evidence available cuts the other way. Cigarette companies continued to advertise heavily after Banzhaf. ${ }^{180}$ Nor is the network's estimate of its reply time obligations convincing, even assuming that its figures are correct. It is highly unlikely that all advertisements for all the products mentioned will be simultaneously subject to fairness doctrine requirenients, and it does not follow that all replies will replace time previously sold to advertisers. But most important, the Commission need not now determine the effect of possible future decisions on broadcaster incoine. It may simply be impossible to predict with confidence which products will be controversial at various times in the future.

It would be more reasonable for the Commission to view each case as it arises, considering for each one the possible financial impact upon the licensee. By limiting its attention to one case at a time, reasonably accurate projections of cost may be available. And, as it deals with each case, the Commission may gain experience that will be useful in later determinations. Furthermore, the burden of persuasion on this issue should rest with the licensee, for it is the party asking the Commission to make an exception to fairness doctrine principles. Also, the licensees have the most complete information regarding their financial condition.

It is likely that $\mathrm{m}$ following sucl a procedure the Commission may never have to choose between licensee solvency and the fairness doctrine. Unless the extreme situation forecast by CBS develops, broadcasters will probably be able to easily absorb the cost of fairness. They apparently absorbed without difficulty the loss resulting from the Congressionally imposed ban of cigarette advertising. A study commissioned by Broadcasting, the industry trade journal, found that

177. Brief for CBS at 13-14.

178. Id.

179. Id. at 14-15.

180. See note 172 supra. 
television and radio substantially maintained their share of total advertising revenues despite a massive shift into the print media by the tobacco coinpanies, who had spent $\$ 220$ million on radio and television advertising in the year before the ban. ${ }^{181}$ This accoinplishment is particularly impressive because the cigarette advertising ban became effective the same year the Commission required the networks to release additional prime time hours to the local stations; this new regulation was assumed to have reduced advertising revenues ineasurably. ${ }^{182}$

Broadcasting quotes one CBS spokesman as saying that the loss of cigarette advertising "made us pare off the fat, but none of the muscle."183 According to Commissioner Johnson, the stations have quite a bit of fat available for paring, since they "average a 90 to 100 percent return on tangible investment annually."184 Obviously the industry will object to any Commission policy which reduces their profits, but the Commission is obligated to protect them only from losses that would endanger their financial viability, not from all decreases in revenue.

If some action is required, the Commission has options short of a complete abandoninent of application of the fairness doctrine to advertisements for controversial products. The Commission could, for example, set an upper limit on the amount of time a licensee would be required to donate. The limit could be set at a level representing the maximum amount of time that most licensees could afford, or it could be set individually for various licensees. The limit would apply to all fairness doctrine obligations, not only those arising from commercials. Whenever meritorious fairness doctrine claims created a need for more time than was available, the Commission could require that available time be apportioned equitably across issues. Variations of sucli a plan have been proposed to the Coinmission. ${ }^{185}$

181. BroAdCASTING, January 10,1972 , at 16 . Although the total advertising revenues declined, the study concluded that this was due at least as much to the economy as to the loss of cigarette revenues. In comparing broadcast revenues with advertising revenues for other media, the study produced these comparisons between 1970 and 1971 (1971 was the first year in which the ban on broadcast eigarette advertising became effective.):

Percent of Total Advertising Revenues

$\begin{array}{lcccccc} & \text { TV } & \text { TV } & & & & \\ & \text { Network } & \text { Spot } & \text { Radio } & \text { Magazine } & \text { Newspaper } & \text { Outdoor } \\ \text { 1970: } & 29 & 21 & 7 & 22 & 18 & 3 \\ \text { 1971: } & 27 & 20 & 7 & 24 & 19 & 3\end{array}$

182. Id.

183. Broadcasting, December 6, 1971, at 47 .

184. N. Jornsson, How to Talk Back to Your Television Set 65 (1969).

185. See e.g., Brief for the National Citizens Committee for Broadcasting, in Heading III, Notice of Inquiry, supra note 11. 
But if the Commission adopted such a compromise plan it would be admitting that full application of the fairness doctrine is incompatible with the commercial base of private broadcasting. Given the suggestion in Red Lion that the fairness doctrine is constitutionally compelled, ${ }^{188}$ this admission would present a serious dilemma that may require a major Congressional reexamination of the financial foundation of American broadcasting.

\section{CONCLUSION}

Over 95 percent of American homes are equipped with television sets. Between his second and sixty-fifth year, the average inale viewer spends 8 years, 24 hours a day, watching television. ${ }^{187}$

Despite this pervasive influence, one commentator has suggested that the impact of television on attitudes and behavior is mimimal. $\mathrm{He}$ argues that few people are influenced by or interested in thorough discussion of controversial issues. ${ }^{188}$ But this argument misses the mark. Persuasion can operate in many ways: ${ }^{189}$ television need not appeal to viewers' interest in intellectual debate to have an impact. Certainly, available data on cigarette consumption supports the conclusion that the anti-smoking inessages had an extensive imipact. ${ }^{190}$

186. 395 U.S. at 390 . Even commentators critical of the value of the fairness doctrine have read Red Lion as compelling it. See L. Jaffe, The Editorial Responsibility of the Broadcaster: Reflections on Fairness and Access, 85 HARV. L. REv. 768, 774 (1972).

Of course it is unclear how much freedom the Commission constitutionally possesses to set the precise contours of the fairness doctrine, even assuming that it is required in some form. It seems plausible that one thing the Commission cannot do is give one category of the public-commercial advertisers-a specially protected place, allowing them to air their views uncontested while others must submit their opinions to national debate. It may be, therefore, that regardless of the validity of the economic argument, neither Congress nor the FCC can solve the problem by simply removing commercial messages from the purview of the fairness doctrine.

187. N. Johnson, How to TAlk BaCk to Your Television Set 13 (1969).

188. L. Jaffe, The Editorial Responsibility of the Broadcaster: Reflections on Fairness and Access, 85 HARv. L. Rev. 768, 770 (1972).

189. See Comment, Fairness Doctrine: Television as a Marketplace of Ideas, 45 N.Y.U. L. Rev. 1222, 1230-31 (1970); Brief for Complainant at 2, in Adoption of Standards Designed to Eliminate Deceptive Advertising from Television, 32 F.C.C. 2d 360 (1971).

190. American cigarette consumption reached a peak in 1967, the year before the Banzhaf ruling. As the anti-cigarette messages began to appear ou the air in late 1968, consumption began to drop for the first time in two years. In 1969 it had slipped to 528.9 billion cigarettes, from the 549.2 billion in 1967 . When cigarette commercials left the air in 1970, so did the anti-smoking messages. Consunption immediately began to climb. 536.4 billion cigarettes were consumed in 1970. [Capital Broadcasting Co. v. Mitchell, 333 F. Supp. 582,589 n.18 (D.D.C. 1971) (Wriglit, J. dissenting).] In 1971, consumption rose to 547.2 billion, and the FTC recommended that the Department of Health, Education and Welfare purchase broadcast time for anti-smoking messages. [BROADCASTING, July 31, 1972, at 23-24.] 
But more fundamentally, it is too late to argue that thorough public ventilation of disparate views is an unimportant value: that policy decision was made with the adoption of the first amendment.

Not only the Commission, ${ }^{191}$ but also Congress ${ }^{192}$ and the Supreme Court ${ }^{193}$ have expressed the view that the Fairness Doctrine is the appropriate tool for protecting this first amendinent interest. As this Comment las shown, limiting the doctrine to non-commercial content is arbitrary and unjustified under the statutory public interest standard, ${ }^{194}$ is unnecessary to protect the Commission from undue administrative burdens, and cannot be supported as necessary to maintain the financial base of radio and television.

Ira Mark Ellman

191. Report on Editorializing by Broadcast Licensees, 13 F.C.C. 1246 (1949); Applicability of the Fairness Doctrine in the Handling of Controversial Issues of Public Importance, 40 F.C.C. 598 (1964); Notice of Inquiry, supra note 11.

192. See note 17, supra.

193. Red Lion Broadcasting Co. v. FCC, 395 U.S. 367 (1969).

194. 47 U.S.C. $\$ \S 307(a), 309$ (a) (1970). 